\title{
STRATEGIC HUMAN RESOURCE MANAGEMENT OF VOLUNTEERS AND THE LINK TO HOSPITAL PATIENT SATISFACTION
}

\author{
Published in: \\ Nonprofit and Voluntary Sector Quarterly, April 2016, 45(2), 409-424. \\ Sean E. Rogers, Ph.D.* \\ School of Hotel Administration \\ Cornell University \\ 565C Statler Hall \\ Ithaca, NY 14853 \\ Tel. 386.453.3887*E-mail: $\underline{\text { ser265@ cornell.edu }}$ \\ Kaifeng Jiang, Ph.D. \\ Department of Management \\ Mendoza College of Business \\ University of Notre Dame \\ 102 Mendoza College of Business \\ Notre Dame, IN 46556 \\ Tel. 312.963.9432*E-mail: kjiang@nd.edu \\ Carmen M. Rogers, Ed.D. \\ School of Hotel Administration \\ Cornell University \\ 180 Statler Hall \\ Ithaca, NY 14853 \\ Tel.607-255-8322*E-mail: cmr288@ cornell.edu
}

Melissa Intindola, Ph.D.

Department of Management

Haworth College of Business

Western Michigan University

3150 Schneider Hall, Mail Stop 5429

Kalamazoo, MI 49008-5457

Tel. 812.972.5516* E-mail: $\underline{\text { melissa.cast@ wmich.edu }}$

* Corresponding author

Authors' Note: Earlier versions of this paper were presented at the 2012 Academy of Management annual meeting, and the University of Notre Dame Mendoza College of Business Global Conference on Social Impact in 2013. We thank attendees at those sessions, the multiple hospital volunteer administrators who graciously reviewed our work and ideas, and the NVSQ editor and anonymous referees for their helpful comments and suggestions.

Keywords: Volunteers, Hospitals, Strategic Human Resource Management, High-Commitment Work Practices, HCAHPS, Patient Satisfaction 


\begin{abstract}
This article uses strategic human resource management theory to consider the ways in which volunteers can potentially enhance hospital patient satisfaction. Results of a structural equation modeling analysis of multi-source data on 107 U.S. hospitals show positive associations between hospital strategy, volunteer management practices, volunteer workforce attributes, and patient satisfaction. While no causality can be assumed, the results shed light on the volunteer-patient satisfaction relationship and have important implications for hospital leaders, volunteer administrators, and future research.
\end{abstract}




\section{INTRODUCTION}

Hospitals increasingly focus their efforts on delivering high-quality patient care while reducing costs. A key aspect of hospital performance is patient satisfaction, and hospital volunteers can potentially enhance patient satisfaction. Brent Hotchkiss et al. (2009), for example, found that greater use of volunteers was related to higher patient satisfaction scores. However, this volunteer-patient satisfaction relationship is not well understood. Referring to prior research that suggests a relationship between volunteers and patient satisfaction, Brent Hotchkiss et al. (2014) note, "Future research further exploring the relationship between these variables and focusing on the development of this relationship could greatly benefit hospitals wishing to improve patient satisfaction" (p. 16). They call for a wide range of approaches to this task, including research from "Experts in the field of volunteerism, economics, and business" ( $p$. $15)$.

We take up their call by examining the volunteer-patient satisfaction link through the lens of strategic human resource management theory, a perspective pervasive in business administration scholarship. Nonprofit scholars have recently encouraged applying a strategic perspective to the study of volunteers. For example, Connors (2012) pointed out a high need for additional research "to demonstrate the value added and the significant impact of effective strategic volunteer engagement" (p. xviii). We believe such an approach holds great promise for understanding the potential of volunteer resource management.

\section{HUMAN RESOURCE MANAGEMENT AS STRATEGIC CHOICE}

Wright and McMahan (1992) define strategic human resource management as "the pattern of planned human resource deployments and activities intended to enable an organization to achieve its goals" (p. 298). Simply put, strategic human resource management highlights the 
strategic importance of purposeful human resource management, or HR (Delery \& Doty, 1996). Within strategic human resource management, a key discussion is that of the relationship between an organization's strategy and the way it manages its workers. In studying the employment practices of American steel mills, Arthur (1992) found a relationship between an organization's strategy as either a cost leader or a differentiator and its HR practices. Cost leaders tended to utilize "cost reduction" or "control" HR practices, whereas differentiators used “commitment-enhancing” HR practices more often. In a 1994 follow-up study, Arthur (1992) empirically demonstrated a link between strategy, HR, and outcomes. Steel mills with commitment-based HR systems experienced better outcomes than mills with cost-reductionbased HR systems. Strategic human resource management researchers have since expanded the list of consequences of "high-commitment" HR to include links to decreased turnover, increased productivity and sales growth, improved corporate financial performance and organizational climate, and greater organizational citizenship and helping behaviors among employees (e.g., Batt, 2002; Cappelli \& Neumark, 2001; Chuang \& Liao, 2010; Guthrie, 2001; and Huselid, 1995).

Applying strategic human resource management theory to the volunteer-patient satisfaction link becomes a potentially useful tool for "focusing on the development of this relationship" (Brent Hotchkiss et al., 2014, p. 16). Does a hospital's approach to volunteer resource management reflect larger organizational characteristics, and does volunteer management relate to volunteer and organizational outcomes? Figure 1 depicts a framework for how these elements might work together, and is based upon conceptual and empirical models from strategic human resource management literature (e.g., Arthur, 1994). In the following 
section we theorize the nature of the relationships among the variables in the conceptual model presented in Figure 1.

\section{[INSERT FIGURE 1 ABOUT HERE]}

\section{LINKS BETWEEN STRATEGY, VOLUNTEER MANAGEMENT, VOLUNTEER ATTRIBUTES, AND PATIENT SATISFACTION}

Drawing upon the work of Arthur (1992) and more recent studies (e.g., Takeuchi, 2009) that demonstrate a link between an organization's strategy and its approach to managing employees, we hypothesize that a hospital's volunteer resource management will reflect a leaning toward cost-reduction or toward quality-maximization. How might this link occur in practice? Arthur's (1992) study revealed that organizations focusing on cost-reduction tended to create HR systems that emphasized minimizing labor costs through direct (e.g., relatively low wages and benefits) and indirect (e.g., narrowly-defined jobs and intense supervision) cost containment. Conversely, organizations concentrating on quality-maximization viewed laborrelated expenses as investments that enabled the production of high-quality goods and services. Such steel mills in Arthur's (1992) study tended to use “commitment-enhancing” HR practices such as relatively high wages, broadly defined jobs, and increased training and development. Similarly, we propose that hospitals with a primarily high-quality strategic orientation will tend to use more frequently commitment-enhancing volunteer resource management. This relationship constitutes hypothesis 1 in Figure 1. The complete list of volunteer management practices we considered is listed in Table 1.

Moving to the right in Figure 1, we draw upon "black box" research in strategic human resource management to explore the relationship between volunteer management and volunteer worker attributes. Early strategic HR research (e.g., Huselid, 1995) demonstrated a link between 
HR practices and firm outcomes. However, the mediating mechanisms and processes (i.e., the variables comprising the then unknown "black box" between HR and outcomes) by which human resource management influenced organizational outcomes were not well understood. Recently, studies have highlighted these mediating mechanisms. A meta-analysis of strategic HR studies by Jiang et al. (2012) describes a sequential process in which human resource management influences worker attitudes, which in turn influence organizational outcomes.

We apply this sequence to develop a model in which volunteer resource management practices relate to volunteer ability to perform job tasks, motivation to perform job tasks, and opportunities to perform job tasks. Commonly referred to in management scholarship as the ability-motivation-opportunity model, Blumberg and Pringle (1982) conceptualized worker performance as a three-dimensional model reflecting one's ability, willingness, and opportunity to perform job tasks. Ability to perform consists of a worker's knowledge, skills, competencies, and other human capital characteristics (Becker, 1975). Willingness to perform speaks to an employee's motivation to exert effort toward his or her work. And opportunity to perform describes whether the appropriate environmental conditions exist that enable workers to do their jobs well. The meta-analysis by Jiang et al. (2012) shows that HR practices influence all three, and we propose that volunteer management practices will also relate to each one. Specifically, greater use of commitment-enhancing volunteer resource management practices will be positively related to these volunteer attributes. These predictions constitute hypotheses $2 \mathrm{a}, 2 \mathrm{~b}$, and $2 \mathrm{c}$ in Figure 1.

The final set of relationships in Figure 1 deals with the impact of volunteer attributes on patient satisfaction. And again, we use the strategic human resource management process model offered by Jiang et al. (2012) to understand this relationship. Handy and Srinivasan (2004) found 
that hospital volunteers engage in a range of patient-contact as well as administrative tasks, including visiting with patients and providing companionship to their families, fundraising, transporting patients, and serving on boards. Hospitals that utilize commitment-enhancing volunteer management practices could potentially be creating pathways for volunteers to directly and indirectly enhance the patient experience. A few hypothetical examples might make this relationship clearer - we offer one example for each of the three domains of ability, motivation, and opportunity to perform.

The practice of providing specific training for volunteers and paid staff on methods of working together to deliver high-quality patient services (the volunteer management practice) may provide volunteers with the skills needed to work alongside hospital paid staff synergistically (the ability to perform) in a way that adds value for patients and enhances their satisfaction (the organizational outcome).

Recruiting and hiring volunteers based on specific skill sets such as fundraising, and then placing them in appropriate roles such as annual fund drives where they can utilize those skills (the volunteer management practice), may position them to do work that they are excited about because they have experience and know they can do it well (the motivation to perform). If the work of these volunteers helps generate relatively higher resources, those resources can be used to enhance the patient experience (the organizational outcome).

The opportunity domain of worker performance is often discussed in relation to employment empowerment. Employees perform better when they feel empowered to do the tasks assigned to them (Blumberg \& Pringle, 1982). If hospital volunteers are given periodic performance evaluations in which they are told the job tasks they are doing very well and the areas that need improvement (the volunteer management practice), then they can adjust their 
work behaviors as needed, continuing to do those tasks they perform well and working to improve weaker areas (the opportunity to perform). This management-enabled, self-reflective sharpening of individual performance might then relate to patient satisfaction (the organizational outcome). Taken together, these examples illustrate our hypotheses 3a, 3b, and 3c.

In this section we have employed a process model of strategic human resource management to develop understanding about the volunteer-patient satisfaction relationship. Next we conduct an exploratory test of this model using data on 107 U.S. hospitals.

\section{DATA AND METHODS}

\section{Sample}

One primary and two secondary data sources were used for this analysis. For the primary data, between October and December 2010 two waves of paper and pencil questionnaires were mailed to volunteer directors at 496 hospitals in five U.S. states in the Northeast and the South. We received 131 completed surveys, for a response rate of $26 \%$; however, missing data reduced our final analytic sample to 107 hospitals. We obtained additional data for the hospitals in our sample from the Hospital Consumer Assessment of Healthcare Providers and Systems (HCAHPS) and the American Hospital Association data viewer website (http://www.ahadataviewer.com/).

Although our survey response rate is not unusually low compared to many strategic HR studies, it is lower than rates recommended by nonprofit scholars (e.g., Hager, Wilson, Pollak, \& Rooney, 2003). To address the threat of nonresponse bias we tested for differences between hospitals that responded and those that did not respond to our survey. Using an approach similar to that of Takeuchi (2009), we conducted independent sample t-tests comparing the means for several hospital variables, including number of hospital admissions, beds available, operating 
expenses, and number of paid employees, for survey respondents and non-respondents. Data for these variables are from the American Hospital Association database. We found no statistically significant differences for any of those variables $(\mathrm{p}<.05)$. Though the threat of nonresponse bias is not totally resolved, we are confident that our subsequent analyses can produce acceptable results.

On average the 107 hospitals that comprise our sample have been operating for 96 years $(\mathrm{SD}=47)$, have 261 patient beds $(\mathrm{SD}=177)$, utilized 341 volunteers over a 12 -month period $(\mathrm{SD}=364)$, and have 1,883 paid employees $(\mathrm{SD}=2,054$; for number of paid employees we used the natural log in analyses). The number of volunteers at each facility was reported by survey respondents, while American Hospital Association data were used to obtain information for the other hospital variables. Most of these organizations were rural or suburban hospitals $(\mathrm{N}=55)$ or metropolitan or urban hospitals $(\mathrm{N}=48)$. Correlations, means, standard deviations, and scale reliabilities are presented in Table 1.

\section{[INSERT TABLE 1 ABOUT HERE]}

\section{Variables}

Organization strategy has typically been assessed in strategic human resource management studies through either the paragraph method or multi-item scales, with the latter being more widely accepted (Takeuchi, 2009). Thus, we used scales, with four items to measure a quality-maximization strategic orientation, and three items to measure a cost-reduction strategic orientation. All items are listed in the Appendix.

To gauge the degree to which an organization's HR practices reflect a commitmentenhancing human resource management system, strategic HR scholars typically compose a list of HR practices and then have respondents indicate the extent to which their organization 
implements each practice. We composed a listing of 23 volunteer resource management practices by reviewing the volunteer management literature. No single list of "best practices" exists, and the lists we retrieved included a different number of, overlap in, and variation across, practices. We settled on 23 practices from four oft-cited publications: Brudney (1999), Ellis (2010), Hager and Brudney (2004), and UPS Foundation (2002). The way the practices were worded in our questionnaire, reflect a commitment-based approach to volunteer management for all 23 items. Thus, we measure higher ratings of usage as indicating a high-commitment volunteer resource management, whereas lower ratings indicate lower levels of commitment. Table 2 lists the volunteer management practices as well as examples of what the administration of each practice might resemble under a commitment-enhancing versus cost-reduction approach.

\section{[INSERT TABLE 2 ABOUT HERE]}

We used established scales from previously-published research to measure worker ability, motivation, and opportunity to perform job tasks (ability: 5-items; Youndt, Subramaniam, \& Snell, 2004; motivation: 3-items; Park, Mitsuhashi, Fey, \& Bjorkman, 2003; and autonomy: 3-items; Hackman, Oldham, Janson, \& Purdy, 1975). Because these scales were not originally designed for volunteer workers, we modified the wording to reflect volunteers. The motivation measure addresses volunteers' motivations to perform their assigned job tasks, not the motives for volunteering or continuing to volunteer.

Patient satisfaction was measured using an average of two HCAHPS items. HCAHPS is a survey instrument that measures hospital inpatients' experiences and perceptions of medical care quality (http://www.hcahpsonline.org/home.aspx). The first reports the percentage of patients who gave the hospital a quality rating of 9 or 10 on a scale from 0 (lowest) to 10 (highest). For this item, a score of zero corresponds to a rating of "worst hospital possible" and 10 corresponds 
to a rating of "best hospital possible." The second reports the percentage of patients who reported they would definitely recommend the hospital to others. About $90 \%$ of all acute care hospitals in the U.S. are represented in the HCAHPS survey findings annually (Giordano, Elliott, Goldstein, Lehrman, \& Spencer, 2009).

In the analysis we controlled for hospital size, the total annual volunteer hours worked, and the ratio of volunteer workers to paid staff. Such variables have been shown to be important in past volunteer analyses (e.g., Hager \& Brudney, 2004; Hager \& Brudney, 2011) and in human resources research (e.g., Guthrie, 2001; Huselid, 1995). We measured hospital size in terms of number of beds.

\section{Analytic Approach}

We used structural equation modeling (SEM) in LISREL 8.72 (Jöreskog \& Sörbom, $2005)$ to test measurement and structural models, and gauged model fit with chi-square $(\chi 2)$, root-mean-square error of approximation (RMSEA), the comparative fit index (CFI), and standardized root mean square residual (SRMR; Kline, 2005). SEM is advantageous over traditional ordinary least squares regression in several aspects, such as allowing for improved construct validity of the variables of interest, providing more accurate parameter estimates, and allowing researchers to test a complicated model with multiple paths simultaneously and compare hypothesized models against alternatives (Wolf \& Brown, 2013). We tested mediation by checking statistical significance of path coefficients of a mediational pathway (Kenny, Kashy, \& Bolger, 1998).

To reduce the number of item parameters included in our structural equation models, we constructed item parcels for organizational strategy (originally 7 items) and volunteer management practices (originally 23 items) using procedures recommended by Hall, Snell, and 
Foust (1999). Item parcels refer to subsets of survey scale items summed or averaged to form composites (in our case, averaged item responses). The seven items representing qualitymaximization and cost-minimization organizational strategies were parceled to form two analytic variables - the quality-maximization and cost-minimization strategic orientations. For volunteer management practices, items representing conceptually distinct categories of practices (for example, training and development or recognition and rewards) were composed into six separate item parcels.

\section{RESULTS}

A five-factor measurement model (organizational strategy, volunteer management practices, volunteer human capital, motivation, and autonomy) fit the data well $\left(\chi^{2}(142)=\right.$ 201.50, $<<.01 ;$ RMSEA = .06; CFI = .97; SRMR = .07), and all factor loadings were significant, suggesting convergent validity of the measures (Anderson \& Gerbing, 1988). In addition, the five-factor measurement model fit the data much better than a model collapsing all items to one factor $\left(\Delta \chi^{2}(10)=646.71, \mathrm{p}<.01 ; \mathrm{RMSEA}=.19 ; \mathrm{CFI}=.80 ; \mathrm{SRMR}=.16\right)$, suggesting the discriminant validity of the measures.

\section{[INSERT FIGURE 2 ABOUT HERE]}

The mediating model also fit the data well $\left(\chi^{2}(238)=439.48, \mathrm{p}<.01 ; \mathrm{RMSEA}=.08\right.$; $\mathrm{CFI}=.91)$. As presented in Figure 2 organizational strategy was positively related to the use of commitment-enhancing volunteer management practices $(\beta=.33, \mathrm{p}<.01)$ after controlling for the effect of hospital size $(\beta=-.18, \mathrm{p}>.05)$, total volunteer hours $(\beta=.62, \mathrm{p}<.01)$, and the ratio of volunteers to paid employees $(\beta=.02, \mathrm{p}>.05)$. Thus, Hypothesis 1 is supported.

A high-commitment volunteer resource management system is also positively related to volunteer ability to perform $(\beta=.46, \mathrm{p}<.01)$, volunteer motivation to perform $(\beta=.18, \mathrm{p}<.05)$, 
and volunteer opportunity to perform $(\beta=.55, \mathrm{p}<.01)$. Thus, Hypotheses $2 \mathrm{a}, 2 \mathrm{~b}$, and $2 \mathrm{c}$ are supported.

We found volunteer ability to perform and opportunity to perform to be positively and significantly related to patient satisfaction $(\beta=.18, \mathrm{p}<.05$ and $\beta=.30, \mathrm{p}<.01$, respectively); however, volunteer motivation to perform was not. Hypotheses $3 \mathrm{a}$ and $3 \mathrm{c}$, but not $3 \mathrm{~b}$, are supported.

\section{DISCUSSION AND CONCLUSION}

In this Research Note we used strategic human resource management theory to explore the volunteer-hospital patient satisfaction relationship. We found associations between hospital strategy, volunteer resource management, volunteer attributes, and patient satisfaction. Although causality cannot be assumed, our results are a preliminary step toward providing the “quantitative research" Brent Hotchkiss et al. (2009) call for to further "explore the relationships that exist between volunteerism and quality deliverables" (p. 16).

Starting from the middle of the model (at volunteer management practices) and moving to the right, our findings suggest that volunteer management and hospital outcomes are positively associated, suggesting the value in further research to determine whether volunteer resource management matters in producing better hospital outcomes. Although a volunteer-patient satisfaction relationship has been an anecdotal "mantra" of hospital volunteer departments, little quantitative evidence heretofore has been produced to demonstrate a link between volunteer resource management and outcomes.

The left side of our model - the organizational strategy-volunteer management utilization link - is also instructive. As Arthur $(1992,1994)$ noted, HR practices reflect an organization's strategic orientation. We find evidence for this relationship in regard to hospitals. Does the 
finding that strategy is related to volunteer resource management mean that hospitals that have a cost-reduction orientation should just accept as fact a relatively lower-commitment approach to volunteer management? Our results suggest that organizational strategies may create cultural and operational dynamics that "pull" or "push" volunteer resource management in certain directions. But any organizational pull toward less active volunteer management need not be the final word. Knowledge of the potential benefits of high-commitment volunteer resource management highlights the need for volunteer directors in resource-limited organizations to place greater emphasis on enacting such systems. Possible low-cost commitment-enhancing volunteer management strategies include the use of verbal recognitions, or the creation of a policy manual for volunteers and employees to help them understand their respective roles.

One departure between our results and the strategic human resource management literature was our finding that volunteer motivation to perform was not positively associated with organizational outcomes (in this case patient satisfaction). Considering our hypothetical staffing example proposed above concerning how motivation to perform might function, the process of fully exploiting the volunteer management-motivation-patient satisfaction relationship is a multipronged one in which volunteers not only need to be recruited strategically but also assigned purposefully to jobs. Perhaps some links in this hypothetical example are missing among the hospitals in our sample. We look forward to investigating motivation to perform and its possible relationship to patient satisfaction.

Our study has several limitations. Our sample was cross-sectional and limited to hospitals in five states in the northeastern and southern U.S. Although our study is partially guarded against common-method bias by the use of data from three different sources (primary data, plus HCAHPS and American Hospital Association datasets), we asked volunteer directors to report 
the attributes of their volunteer workforces as opposed to obtaining those data from the volunteers themselves. Finally, our model leaves out a number of plausible explanations for a link between hospital strategic orientation and HCAHPS patient satisfaction scores, including employee performance and facility-specific characteristics (e.g., state-of-the-art buildings and equipment). Future research should develop more sophisticated models of the volunteer-patient satisfaction link and continue to fill-in the "black box" between volunteer management and organizational outcomes.

Volunteer administrators often lament that their efforts are underappreciated or go unnoticed. In the face of a changing healthcare system and an increasing concern with patient outcomes, our findings provide preliminary evidence that commitment-enhancing volunteer resource management is linked to patient satisfaction. If future research should support this narrative, it will become increasingly easy to justify investing organizational resources in volunteer administration and the volunteer workforce. 


\section{REFERENCES}

Anderson, J. C., \& Gerbing, D. W. (1988). Structural equation modeling in practice: A review and recommended two-step approach. Psychological bulletin, 103, 411-423.

Arthur, J. B. (1992). The link between business strategy and industrial relations systems in American steel minimills. Industrial and Labor Relations Review, 45, 488-506.

Arthur, J. B. (1994). Effects of human resource systems on manufacturing performance and turnover. Academy of Management Journal, 37, 670-687.

Batt, R. (2002). Managing customer services: Human resource practices, quit rates, and sales growth. Academy of Management Journal, 45, 587-597.

Becker, G. (1975). Human capital: A theoretical and empirical analysis with special reference to education. New York: Columbia University Press.

Blumberg, M., \& Pringle, C. D. (1982). The missing opportunity in organizational research: Some implications for a theory of work performance. The Academy of Management Review, 7, 560-569.

Brent Hotchkiss, R., Fottler, M. D., \& Unruh, L. (2009). Valuing volunteers: The impact of volunteerism on hospital performance. Health Care Management Review, 34(2), 119128.

Brent Hotchkiss, R., Fottler, M. D., \& Unruh, L. (2014). The role, measurement, and impact of volunteerism in hospitals. Nonprofit and Voluntary Sector Quarterly, 43(6), 1111-1128.

Brudney, J. L. (1999). The effective use of volunteers: Best practices for the public sector. Law and Contemporary Problems, 62, 219-255.

Cappelli, P., \& Neumark, D. (2001). Do high-performance work practices improve establishment-level outcomes? Industrial and Labor Relations Review, 54, 737-775.

Chuang, C-H., \& Liao, H. (2010). Strategic human resource management in service context: Taking care of business by taking care of employees and customers. Personnel Psychology, 63, 153-196.

Connors, T. D. (2012). The Volunteer Management Handbook: Leadership Strategies for Success. Hoboken, NJ: John Wiley \& Sons, Inc.

Delery, J. E., \& Doty, D. H. (1996). Modes of theorizing in strategic human resource management: Tests of universalistic, contingency, and configurational performance predictions. Academy of Management Journal, 39, 802-835. 
Ellis, S. J. (2010). From the top down: The executive role in successful volunteer involvement. Philadelphia, P.A.: Energize, Inc.

Giordano, L. A., Elliott, M. N., Goldstein, E., Lehrman, W. G., \& Spencer, P. A. (2009). Development, implementation, and public reporting of the HCAHPS survey. Medical Care Research and Review.

Guthrie, J.P. (2001). High involvement work practices, turnover, and productivity: Evidence from New Zealand. Academy of Management Journal, 44, 180-190.

Hackman, J. R., Oldham, G., Janson, R., \& Purdy, K. A. (1975). New strategy for job enrichment. California Management Review, 17, 57-71.

Hager, M. A., \& Brudney, J. L. (2004). Volunteer Management Practices and Retention of Volunteers. Washington, D. C.: The Urban Institute.

Hager, M. A., \& Brudney, J. L. (2011). Problems recruiting volunteers: Nature versus nurture. Nonprofit Management and Leadership, 22(2), 137-157.

Hager, M. A., Wilson, S., Pollak, T. H., \& Rooney, P. M. (2003). Response rates for mail surveys of nonprofit organizations: A review and empirical test. Nonprofit and Voluntary Sector Quarterly, 32(2), 252-267.

Hall, R. J., Snell, A. F., \& Foust, M. S. (1999). Item parceling strategies in SEM: Investigating the subtle effects of unmodeled secondary constructs. Organizational Research Methods, 2(3), 233-256.

Handy, F., \& Srinivasan, N. (2004). Valuing volunteers: An economic evaluation of the net benefits of hospital volunteers. Nonprofit and Voluntary Sector Quarterly, 33(1), 28-54.

Huselid, M. A. (1995). The impact of human resource management practices on turnover, productivity, and corporate financial performance. Academy of Management Journal, 38, 635-672.

Jiang, K., Lepak, D. P., Hu, J, and Baer, J. (2012). How does human resource management influence organizational outcomes? A meta-analytic investigation of mediating mechanisms. The Academy of Management Journal, 55, 1264-1294.

Jöreskog, K. G., \& Sörbom, D. (2005). LISREL 8.7 for Windows. Lincolnwood, IL. URL http://www. ssicentral. com/lisrel.

Kenny, D. A., Kashy, D. A., \& Bolger, N. (1998). Data analysis in social psychology. The Handbook of Social Psychology, 1, 233-265. 
Kline, R. B. (2005). Principles and practice of structural equation modeling (2nd ed.). New York : Guilford Press.

Park, H. J., Mitsuhashi, H., Fey, C. F., \& Björkman, I. (2003). The effect of human resource management practices on Japanese MNC subsidiary performance: A partial mediating model. The International Journal of Human Resource Management, 14, 1391-1406.

Takeuchi, N. (2009). How Japanese manufacturing firms align their human resource policies with business strategies: Testing a contingency performance prediction in a Japanese context. International Journal of Human Resource Management, 20, 34-56.

The UPS Foundation. (2002). A guide to investing in volunteer resources management: Improve your philanthropic portfolio, Retrieved March 7, 2011, from http://www.energizeinc.com/art/documents/invest_vrm_guide.pdf.

Wolf, E.J., \& Brown, T.A. (2013). Structural equation modeling: Applications in the study of psychopathology. In J.S. Comer \& P.C. Kendall (Eds.), Oxford handbook of research strategies for clinical psychology (pp. 287-316). New York: Oxford University Press.

Wright, P. M., \& McMahan, G. C. (1992). Theoretical perspectives for strategic human resource management. Journal of Management, 18, 295-320.

Youndt, M. A., Subramaniam, M., \& Snell, S. A. (2004). Intellectual capital profiles: An examination of investments and returns. Journal of Management, 41(2), 335-361. 


\section{APPENDIX}

$\underline{\text { Hospital Strategy }}$

"The following statements refer to your hospital in general. Please indicate your level of agreement with each statement." (1-5 scaling)

\section{Quality-Maximizing Orientation}

- My hospital seeks to provide the highest quality patient care, even if it means higher costs for the hospital and its patients.

- My hospital prides itself on delivering higher patient satisfaction than other hospitals.

- My hospital provides its paid employees above-industry-average wages and benefits.

- My hospital prides itself on having modern and technologically-advanced medical facilities and equipment, even if it means spending more money.

\section{Cost-Reduction Orientation}

- Keeping operating costs and employee costs to a minimum is very important to my hospital.

- My hospital provides patients the care they need, but doesn't go out of its way to be an industry leader, especially if that means spending extra money.

- My hospital doesn't have a wealth of money and resources, so upgrades to buildings and medical equipment sometimes lag behind other hospitals.

\section{$\underline{\text { Volunteer Ability, Motivation, and Opportunity to Perform }}$}

"The following has to do with your overall assessment of the performance and workplace behaviors of your volunteer workforce, in general. When answering, think of your volunteer workforce as a whole. Do not base your response on one, or a small portion, of your volunteers. Please indicate how often your volunteers exhibit the following workplace behaviors." (1-5 scaling)

\section{"OUR VOLUNTEERS..."}

\section{Ability to Perform}

- Are highly skilled

- Are widely considered the best in our industry

- Are creative and bright

- Are experts in their particular jobs and functions

- Develop new ideas and knowledge

\section{Motivation to Perform}

- Are always behaving in ways that help our hospital's performance 
- Are always contributing in positive ways to the hospital's performance

- Are a highly motivated group of volunteers, compared with other hospitals

\section{Opportunity to Perform}

- My hospital's volunteer jobs are arranged to give volunteers the chance to use their personal judgment in carrying out their work.

- My hospital's volunteer jobs allow volunteers to take part in making decisions that affect their work.

- My hospital's volunteer jobs give volunteers considerable opportunity for independence and freedom in how they do their work. 
Table 1 - Correlation Matrix for Study Variables

\begin{tabular}{|c|c|c|c|c|c|c|c|c|c|c|}
\hline & Mean & SD & 1 & 2 & 3 & 4 & 5 & 6 & 7 & 8 \\
\hline 1. Hospital size $(\ln )$ & 5.24 & .89 & & & & & & & & \\
\hline 2. Volunteer hours $(\ln )$ & 6.18 & 1.32 & $.58 * *$ & & & & & & & \\
\hline 3. Volunteer/staff ratio & .70 & 3.18 & $-.34 * *$ & $-.24 * *$ & & & & & & \\
\hline 4. Hospital strategy & 3.49 & .57 & .12 & $.21 *$ & .06 & $(.65)$ & & & & \\
\hline 5. Volunteer HR & 3.71 & .63 & $.24 * *$ & $.47 * *$ & -.07 & $.26 * *$ & $(.83)$ & & & \\
\hline 6. Ability to perform & 3.78 & .68 & -.13 & .11 & .12 & $.31 * *$ & $.39 * *$ & $(.87)$ & & \\
\hline 7. Motivation to perform & 4.11 & .65 & -.09 & .12 & .15 & $.22 *$ & $.18^{*}$ & $.70 * *$ & $(.78)$ & \\
\hline 8. Opportunity to perform & 3.70 & .81 & -.10 & .13 & .10 & .15 & $.42 * *$ & $.33 * *$ & $.18^{*}$ & $(.76)$ \\
\hline 9. Patient satisfaction ratings & 66.27 & 8.24 & -.12 & $.23 *$ & .13 & $.40^{* *}$ & $.25^{*}$ & $.25^{* *}$ & .16 & $.30 * *$ \\
\hline
\end{tabular}

Coefficients reported in the parentheses are the internal reliabilities. 
Table 2 - Twenty-Three Volunteer Resource Management (VRM) Practices, and Examples of Low-Commitment and HighCommitment Approaches to Volunteer Management

\begin{tabular}{|c|c|c|}
\hline VRM Practice & Low-Commitment Approach to VRM & High-Commitment Approach to VRM \\
\hline $\begin{array}{l}\text {-Written statement of philosophy } \\
\text { regarding volunteer involvement }\end{array}$ & No written philosophy & $\begin{array}{l}\text { Formal, written philosophy widely } \\
\text { available to volunteers and paid staff }\end{array}$ \\
\hline $\begin{array}{l}\text {-Written position descriptions for } \\
\text { volunteer roles }\end{array}$ & No written volunteer position descriptions & $\begin{array}{l}\text { Detailed written volunteer position } \\
\text { descriptions }\end{array}$ \\
\hline $\begin{array}{l}\text {-Written policies and procedures for } \\
\text { paid staff working with volunteers }\end{array}$ & $\begin{array}{l}\text { No written policies and procedures for } \\
\text { paid staff working with volunteers }\end{array}$ & Formal written policies for paid staff \\
\hline $\begin{array}{l}\text {-Periodic needs assessment to } \\
\text { determine how volunteers should } \\
\text { be involved to address the mission }\end{array}$ & No periodic needs assessments & $\begin{array}{l}\text { Deliberate and strategic needs assessment } \\
\text { performed periodically }\end{array}$ \\
\hline $\begin{array}{l}\text {-Liability coverage or insurance } \\
\text { protection for volunteers }\end{array}$ & No coverage & Some form of coverage \\
\hline $\begin{array}{l}\text {-Reimbursement for work-related } \\
\text { expenses of volunteers }\end{array}$ & None & Full reimbursement \\
\hline $\begin{array}{l}\text {-Multiple media outlets (Internet, } \\
\text { direct mail, volunteer recruiting fairs, } \\
\text { etc.) used to recruit volunteers }\end{array}$ & Limited outreach and recruiting activities & $\begin{array}{l}\text { Extensive outreach and recruiting } \\
\text { activities, using multiple media }\end{array}$ \\
\hline $\begin{array}{l}\text {-Volunteers are sought out based on } \\
\text { having skills that match position } \\
\text { requirements }\end{array}$ & $\begin{array}{l}\text { Skills-match is a low priority when } \\
\text { selecting volunteers for hire }\end{array}$ & $\begin{array}{l}\text { Skills-match is crucial in volunteer } \\
\text { recruitment }\end{array}$ \\
\hline $\begin{array}{l}\text {-Formal volunteer screening and } \\
\text { selection process (including position } \\
\text { applications, interviews, background } \\
\text { checks, reference checks, etc.) }\end{array}$ & $\begin{array}{l}\text { Informal, unstructured screening and } \\
\text { selection process }\end{array}$ & $\begin{array}{l}\text { Deliberate, structured screening and } \\
\text { selection procedures }\end{array}$ \\
\hline
\end{tabular}


-Orientation for new volunteers - Ongoing training and professional development for volunteers - Training for paid staff in working with volunteers

-Paid staff new hires are told about why and how volunteers are involved in the organizations work

-Volunteer administrator professional development activities

-Designated administrator responsible for overseeing the management of volunteers agency-wide (for example, Director of Volunteers)

-Volunteer administrator is involved in Not included top-level organizational planning -Supervision of volunteers

-Every volunteer has a designated supervisor (could be one supervisor for multiple volunteers)
No official new-volunteer orientation

Little or no ongoing training and development

No training for paid staff working with volunteers

Volunteer involvement information not provided during paid staff new-hire orientation

Administrator not provided funding for professional development

No dedicated volunteer administrator

High degree of direct supervision; volunteers are managed "to task"

No
Formal, structured orientation

Extensive training and development opportunities

Formal training for paid staff

Newly-hired paid staff are briefed on the role and involvement of volunteers

Volunteer administrator given allowance to join relevant professional associations, subscribe to journals or publications, or attend conferences

Dedicated volunteer administrator

Key player in organizational strategic planning

Low degree of direct supervision; volunteers are allowed to manage themselves

Yes 
-Formal conflict resolution or grievance procedures for volunteers

-Volunteers are provided information about organizational issues and events

-Newsletter for volunteers

- Rewards and activities for recognizing volunteers and their contributions

- Rewards and activities for paid staff recognizing their support for volunteers
No formalized grievance procedures

Not regularly

None

Limited rewards and recognition activities

Limited rewards and recognition activities for paid staff working with volunteers
Formal, institutionalized, and codified conflict resolution procedure

Volunteers receive regular updates

Yes

Consistent rewards structure for volunteers, and regular recognition activities

Consistent rewards structure and recognition activities, for paid staff working with volunteers 
Figure 1 - Conceptual Model of the Volunteer-Patient Satisfaction Relationship

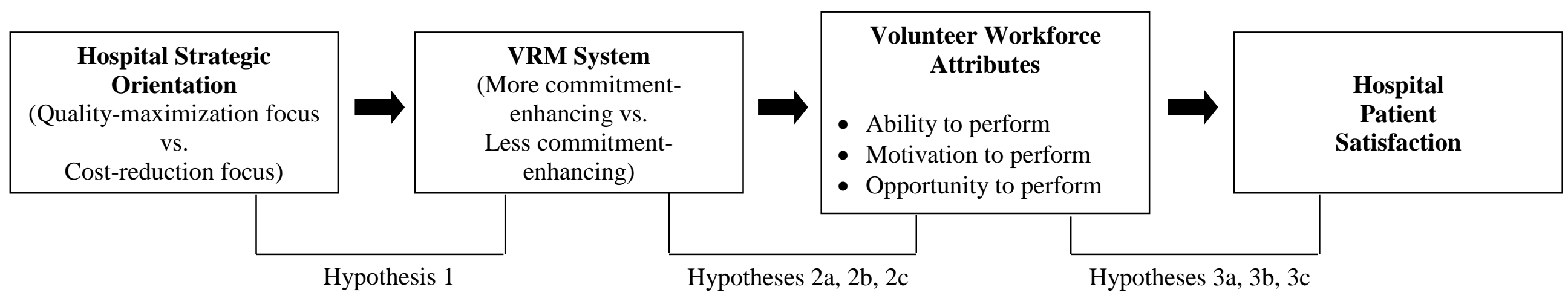


Figure 2 - Structural Equation Model of the Relationship between Hospital Strategy, Volunteer Resource Management Practices, Volunteer Attributes, and Patient Satisfaction

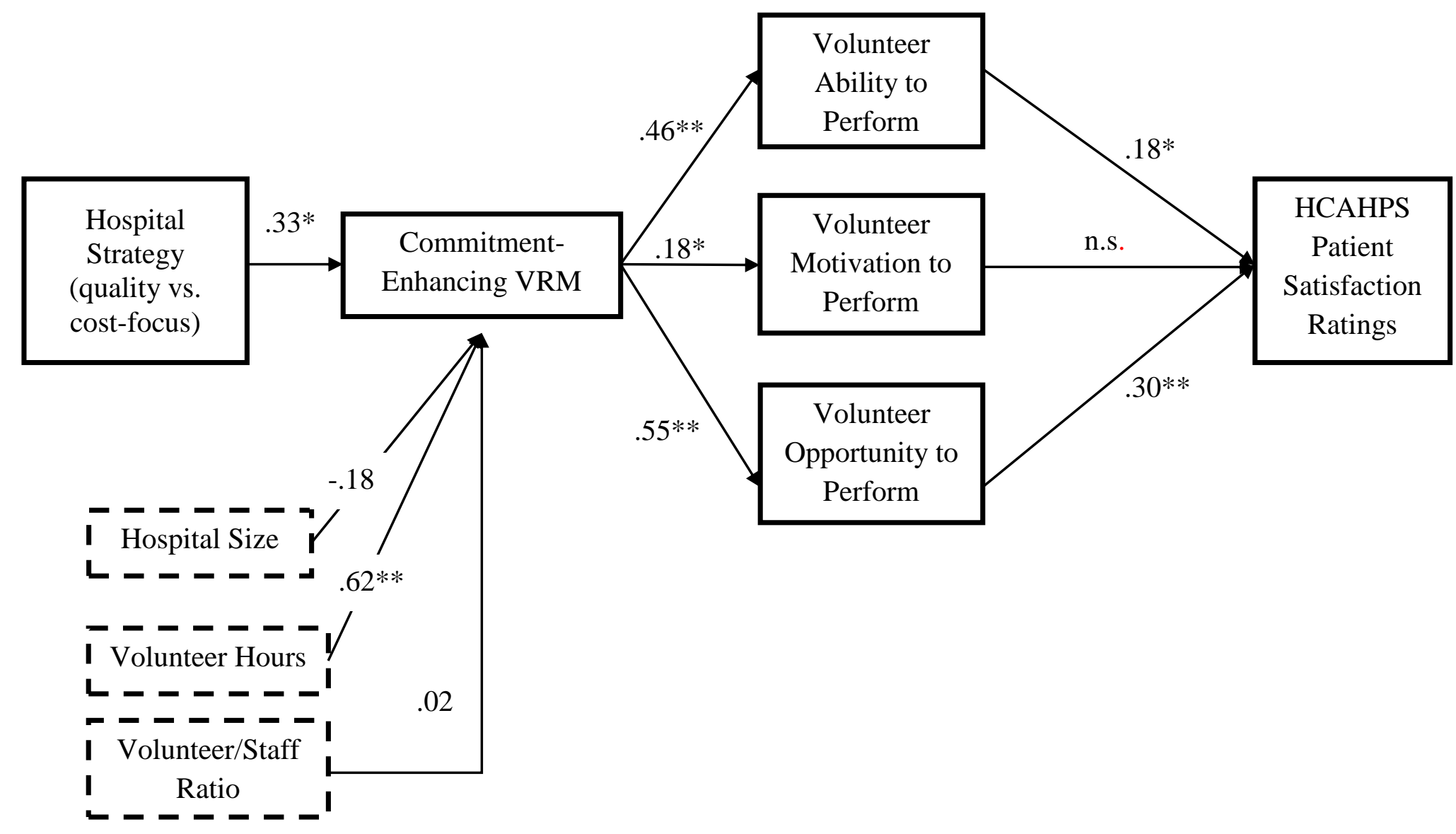

$n=107 . * p<.05 * * p<.01 . \mathrm{n} . \mathrm{s}=$ not statistically significant. 